\title{
The American Academy of Neurology position statement on abuse and violence
}

Elliott A. Schulman, MD, FAAN

Anna DePold Hohler, MD, FAAN

Correspondence \& reprint requests to Dr. Schulman: esmdha@gmail.com

Neurology ${ }^{\circledR} 2012 ; 78: 433-435$
Neurologists see patients with neurologic disabilities that render them susceptible to abuse or neglect. They also encounter patients with neurologic dysfunction that may be either directly or indirectly related to maltreatment. In 2008, the American Medical Association (AMA) encouraged physicians to "routinely inquire about the family violence histories of their patients, as this knowledge is essential for effective diagnosis and care." ${ }^{1}$ Consensus-based guidelines for identification of intimate partner violence (IPV) have been adopted by numerous medical specialty organizations. ${ }^{2-11}$ The US Department of Health and Human Services has recommended that women be screened and counseled for domestic abuse. ${ }^{12}$

PURPOSE OF THE POSITION STATEMENT The consequences of not asking about IPV might include further physical and emotional harm, treatment failure, and when children are exposed, perpetuation of the intergenerational cycle of abuse. ${ }^{13-15}$ Providing resources to those being abused can result in improved outcomes. ${ }^{16}$ Further, identification of an abuse history may influence the assessment and treatment of presenting health concerns. ${ }^{17,18}$ By identifying this issue, and providing an appropriate referral, neurologists may improve quality of life and potentially ameliorate neurologic disability. The AAN is endorsing the assessment of abuse and neglect in our patients and supports the education of the neurologic community to achieve this end. Additional research on the physiologic and psychological consequences of abuse may lead to better treatment strategies to prevent related adverse health outcomes.

DEFINITIONS OF ABUSE Abuse may be defined in a variety of ways. The following definitions are from Kruger and Moon. ${ }^{19}$

- Physical abuse: A willful act carried out with the intent of causing pain or injury.

- Emotional abuse (including bullying and financial abuse): Willful act executed to cause emotional pain, injury, or mental anguish.
- Sexual abuse: Nonconsensual sexual activity.

- Child abuse: Any type of cruelty inflicted upon a child.

- Elder abuse: Abuse or neglect of an individual 65 years of age or older, and those who are physically or mentally disabled.

ABUSE AND ITS RELATIONSHIP TO NEUROLOGIC DISEASES Abuse can effect the development of neurologic disease. More than $90 \%$ of all injuries from IPV occur to the head, face, or neck region $^{20,21}$ and may be associated with traumatic brain injury (TBI). The consequences of lifetime exposure to violence and abuse commonly include neurologic problems. ${ }^{20}$ The short- and long-term consequences of adverse childhood experiences, including abuse and neglect, can result in a multitude of physical and social problems. ${ }^{22}$ Headaches, ${ }^{23-28}$ fibromyalgia, chronic pain syndromes, syncope, and psychogenic nonepileptic seizure have been linked to abuse. ${ }^{29-32}$ In addition, adults who were exposed to parental verbal abuse experienced higher rates of depression, irritability, and somatization. ${ }^{33}$ Finally, patients with physical (e.g., Parkinson disease or stroke) and mental disabilities (e.g., Alzheimer disease) are at higher risk for being abused or neglected than their counterparts. ${ }^{34-36}$

\section{PRINCIPLES OF INTERVENTION IN ABUSE AND NEGLECT}

1. The physician should routinely screen all patients for past and ongoing violence, fully integrating the questions into the medical history.

2. Patients should be treated with respect and dignity.

3. Optimally, patients should be questioned when alone. This is essential when questioning children about abuse.

4. If spousal abuse is present, ask if child abuse is also occurring.

5. Do not blame patients or force them to prove their "victimhood."

6. Document the abuse as reported (who, what, where, when, and what type).

From the Lankenau Medical Center and Lankenau Institute for Medical Research and Jefferson School of Medicine (E.A.S.), Wynnewood, PA; and Boston University Medical Center (A.D.H.), Boston, MA.

Disclosure: Author disclosures are provided at the end of the article. 
7. Use established protocols once abuse is identified. Most guidelines for managing IPV are based on the emergency medicine literature. Specific treatment interventions for women exposed to violence have not been adequately evaluated. ${ }^{37}$ The $\mathrm{AMA}^{38}$ suggests assessing immediate risk, providing police and legal options, safety planning, and providing intervention to assess depression.

8. Child abuse, elder abuse, and abuse of those who are disabled must be reported in all states. Spousal abuse must be reported in California, Colorado, Kentucky, New Hampshire, New York, and Rhode Island.

9. Provide resources. The aim of the neurologist should be to identify abuse and support the patient through referral. ${ }^{39}$ Social workers, victim advocates, hospital staff, support group leaders, hotlines, and Web site resources are all reasonable options.

10. Neurologists should support multidisciplinary efforts to recognize, treat, and prevent abuse and IPV.

SUGGESTED ASSESSMENT QUESTIONS AND STRATEGIES Patients often need to be asked multiple times before acknowledging abuse.

Information gathering can occur by having new patients fill out a questionnaire in the office or at home. Questions on abuse can be listed in the social history section. If answered in the affirmative, clarify whether the abuse is sexual, emotional/financial, or physical. When self-administered questionnaires are followed by a brief discussion of the subject, the most reliable responses are obtained. ${ }^{40}$

Patients may also be asked about abuse directly. These questions may include the following:

- Have you ever witnessed violence?

- Have you ever been hit, kicked, punched, or otherwise physically abused?

- Has anyone ever tried to control you by threat or intimidation?

- Have you ever felt controlled or isolated by your partner?

- Have you ever been forced to perform sexual acts?

- Have you ever been taken advantage of financially?

- Have you ever been concerned for your safety?

Regardless of whether patients are currently being abused or have been abused in the past, offer a referral to a support group or domestic violence advocate.

For patients currently being abused, enlist in-depth safety planning by a trained health care provider, social worker, or abuse prevention advocate, and encourage patients to utilize advocacy services in conjunction with mental health services, if indicated. ${ }^{41}$

For patients with a past history of abuse, help the patient to understand how a history of victimization may be related to current or past health problems and risk behaviors, and explain to the patient that survivors can benefit from advocacy and counseling services even if the abuse was many years or decades earlier.

\section{PATIENT RESOURCES}

- National Domestic Violence Hotline, 1-800799-SAFE (7233) or TTY 1-800-787-3224; www.thehotline.org

- National Sexual Assault Hotline, 1-800-6564673; www.rainn.org

- Futures Without Violence (formerly Family Violence Prevention Fund/Health Resource Center), 1-800-799-7233; www.futureswithoutviolence.org

- National Clearinghouse on Abuse in Later Life; www.ncal.us

- National Organization for Victim Assistance (NOVA), 1-800-879-6682; www.trynova.org

- National Resource Center on Domestic Violence

- Manweb: A Web site with information for battered men; www.batteredmen.com

- Child Welfare Information Gateway; www. childwelfare.gov/responding/reporting.cfm

- National Center on Elder Abuse, 302-8313525; www.ncea.aoa.gov

\section{PHYSICIAN RESOURCES}

- Futures Without Violence (www.futureswith outviolence.org)

- Centers for Disease Control and Prevention

- Academy on Violence and Abuse

- ACOG: Violence against Women

- ACE_Score_1 pg Calculator ${ }^{22}$

\section{AUTHOR CONTRIBUTIONS}

Dr. Schulman: drafting/revising the manuscript, study concept or design, acquisition of data. Dr. Hohler: drafting/revising the manuscript, study concept or design, analysis or interpretation of data, acquisition of data, statistical analysis, study supervision.

\section{ACKNOWLEDGMENT}

The authors thank the members and staff of the Patient Safety Subcommittee and the Practice Committee for their advice in the preparation of this manuscript, specifically Ellis Diamond, MD (cochair); Michael Kaminski, MD (cochair); Barney Stern, MD, FAAN; Samuel Frank, MD; Jonathan Hosey, MD, FAAN; Jessica Doyle Lee, MD; Charles Flippen, MD, FAAN; John Schaffer, MD; Amy Wallace; and Sarah Tonn. The authors also thank Loretta Rossino and Kate Ciavarelli for word processing assistance.

\section{DISCLOSURE}

Dr. Schulman has received funding for travel from NuPathe Inc.; serves as a consultant for NuPathe Inc.; serves on speakers' bureaus for NuPathe Inc., Merck Serono, and GlaxoSmithKline; received an education grant from NuPathe Inc.; and holds stock/stock options in Johnson \& Johnson, Express Scripts, VarianMedical, Novartis, QuestDiagnostic, and Baxter International Inc. Dr. Hohler has received speaker honoraria from the American Parkinson's Disease Association and the United States Army.

Received February 2, 2011. Accepted in final form October 7, 2011. 


\section{REFERENCES}

1. American Medical Association. National Advisory Council on Violence and Abuse (Policy Compendium). American Medical Association; 2008.

2. Committee on Child Abuse and Neglect. The role of the pediatrician in recognizing and intervening on behalf of abused women. Pediatrics 1998;101:1091-1092.

3. American College of Obstetricians and Gynecologists. Domestic Violence: Tech Bull 209. American College of Obstetricians and Gynecologists; 1995.

4. American College of Emergency Physicians. Emergency medicine and domestic violence. Ann Emerg Med 1995; 25:442-443.

5. Emergency Nurses Association. Position Statement: Domestic Violence. Park Ridge, IL: Emergency Nurses Association; 1994.

6. The AAFP Commission on Special Issues and Clinical Interests. Family violence: an AAFP white paper. Am Fam Physician 1994;50:1636-1640, 1644-1648.

7. US Department of Health and Human Services. Healthy People 2000: National Health Promotion and Disease Prevention Objectives: DHHS Pub. No. (PHS) 91-50212. Washington, DC: US Department of Health and Human Services; 1991:237.

8. Joint Commission on Accreditation of Healthcare Organizations. Accreditation Manual for Hospitals, Vol. 1 Standards. Oakbrook Terrace, IL: Joint Commission on Accreditation of Healthcare Organizations; 1992:21-22.

9. American Dental Association. Position Statement on Family Violence. Chicago: American Dental Association; 1996.

10. American College of Nurse Midwives. Position Statement on Violence Against Women. Washington, DC: American College of Nurse Midwives; 1995.

11. American Nursing Association. Position Statement: Physical Violence Against Women. Washington, DC: American Nursing Association; 1991.

12. Available at: http://www.iom.edu/Reports/2011/ClinicalPreventive-Services-for-Women-Closing-the-Gaps.aspx. Accessed on August 15, 2011.

13. McKibben L, De Vos E, Newberger EH. Victimization of mothers of abused children: a controlled study. Pediatrics 1989;84:531-535.

14. Osofsky JD. The impact of violence on children. Future Child 1999;9:33-49.

15. Ross SM. Risk of physical abuse to children of spouse abusing parents. Child Abuse Negl 1996;20:589-598.

16. Tiwari A, Leung WC, Leung TW, Humphreys J, Parker B, Ho PC. A randomised controlled trial of empowerment training for Chinese abused pregnant women in Hong Kong. BJOG Int J Obstet Gynaecol 2005;112:1249-1256.

17. Drossman DA, Li Z, Leserman J, Toomey TC, Hu YJ. Health status by gastrointestinal diagnosis and abuse history. Gastroenterology 1996;110:999-1007.

18. Roberts SJ. The sequelae of childhood sexual abuse: a primary care focus for adult female survivors. Nurse Pract 1996;21:42, 45, 49-52.

19. Kruger RM, Moon CH. Can you spot the signs of elder mistreatment? Postgrad Med 1999;106:169-173.

20. Dolezal T, McCollum D, Callahan M. Hidden Costs in Health Care: The Economic Impact of Violence and Abuse. Eden Prairie, MN: The Academy on Violence and Abuse; 2009.

21. Monahan K, O'Leary K. Head injury and battered women: an initial inquiry. Health Soc Work 1999;24:269-278.

22. Available at: www.ACEStudy.org. Accessed on August 15, 2011.
23. Tietjen GE, Brandes JL, Peterlin BL, et al. Childhood maltreatment and migraine (part I): prevalence and adult revictimization: a multicenter headache clinic survey. Headache 2009;50:20-31.

24. Tietjen GE, Brandes JL, Peterlin BL, et al. Childhood maltreatment and migraine (part II): emotional abuse as a risk factor for headache chronification. Headache 2009;50:32-41.

25. Tietjen GE, Brandes JL, Peterlin BL, et al. Childhood maltreatment and migraine (part III): association with comorbid pain conditions. Headache 2009;50:42-51.

26. Cripe SM, Sanchez SE, Gelaye B, Sanchez E, Williams MA. Association between intimate partner violence, migraine and probable migraine. Headache 2011;51:208-219.

27. Golding JM. Sexual assault history and headache: five general population studies. J Nerv Ment Dis 1999;187:624-629.

28. McCauley J, Kern DE, Kolodner K, et al. Clinical characteristics of women with a history of childhood abuse: unhealed wounds. JAMA 1997;277:1362-1368.

29. Fiszman A, Alves-Leon SV, Nunes RG, D’Andrea I, Figueira I. Traumatic events and posttraumatic stress disorder in patients with psychogenic nonepileptic seizures: a critical review. Epilepsy Behav 2004;5:818-825.

30. Paras ML, Murad MH, Chen LP, et al. Sexual abuse and lifetime diagnosis of somatic disorders: a systematic review and meta-analysis. JAMA 2009;302:550-561.

31. Roelofs K, Keijsers GP, Hoogduin KA, Naring GW, Moene FC. Childhood abuse in patients with conversion disorder. Am J Psychiatry 2002;159:1908-1913.

32. Selkirk M, Duncan R, Oto M, Pelosi A. Clinical differences between patients with nonepileptic seizures who report antecedent sexual abuse and those who do not. Epilepsia 2008;49:1446-1450.

33. Choi J, Jeong B, Rohan ML, Polcari AM, Teicher MH. Preliminary evidence for white matter tract abnormalities in young adults exposed to parental verbal abuse. Biol Psychiatry 2009;65:227-234.

34. Cooney C, Howard R, Lawlor B. Abuse of vulnerable people with dementia by their carers: can we identify those most at risk? Int J Geriatr Psychiatry 2006;21:564-571.

35. Jones JS, Holstege C, Holstege H. Elder abuse and neglect: understanding the causes and potential risk factors. Am J Emerg Med 1997;15:579-583.

36. Utley R. Screening and intervention in elder abuse. Home Care Provider 1999;4:198-201.

37. WathenNC, MacMillan HL. Interventions for violence against women. JAMA 2003;289:589-600.

38. American Medical Association, Council on Scientific Affairs. Violence against women: relevance for medical practitioners. JAMA 1992;267:3184-3189.

39. Rittmayer J, Roux G. Relinquishing the need to "fix it": medical intervention with domestic abuse. Qual Health Res 1999;9:166-181.

40. Glass N, Dearwater S, Campbell JK. Intimate partner violence screening and intervention: data from eleven Pennsylvania and California community hospital emergency departments. J Emerg Nurs 2001;27:141-149.

41. National Consensus Guidelines: The Family Violence Prevention Fund on Identifying and Responding to Domestic Violence Victimization in Health Care Settings. 2004. Available at: http://www.futureswithoutviolence.org/ userfiles/file/HealthCare/consensus.pdf. Accessed on December 22, 2011. 


\section{Neurology}

The American Academy of Neurology position statement on abuse and violence Elliott A. Schulman and Anna DePold Hohler

Neurology 2012;78;433-435 Published Online before print January 25, 2012

DOI 10.1212/WNL.0b013e318245d21c

This information is current as of January 25, 2012

\section{Updated Information \&} Services

References

Citations

Permissions \& Licensing

Reprints including high resolution figures, can be found at: http://n.neurology.org/content/78/6/433.full

This article cites 29 articles, 0 of which you can access for free at: http://n.neurology.org/content/78/6/433.full\#ref-list-1

This article has been cited by 1 HighWire-hosted articles: http://n.neurology.org/content/78/6/433.full\#\#otherarticles

Information about reproducing this article in parts (figures,tables) or in its entirety can be found online at:

http://www.neurology.org/about/about_the_journal\#permissions

Information about ordering reprints can be found online:

http://n.neurology.org/subscribers/advertise

Neurology ${ }^{\circledR}$ is the official journal of the American Academy of Neurology. Published continuously since 1951, it is now a weekly with 48 issues per year. Copyright Copyright $@ 2012$ by AAN Enterprises, Inc.. All rights reserved. Print ISSN: 0028-3878. Online ISSN: 1526-632X.

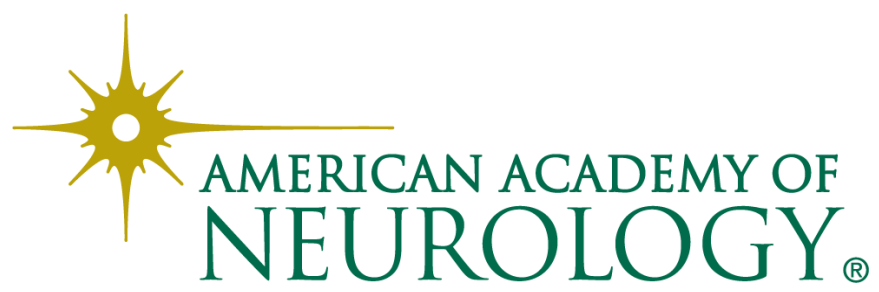

